\title{
In vitro rumen methane output of forb species sampled in spring and summer
}

\author{
Peter J. Purcell ${ }^{1,2}$, Tommy M. Boland ${ }^{2}$, Martin O’Brien ${ }^{1}$ and Pádraig O'Kiely ${ }^{1 *}$ \\ ${ }^{1}$ Animal \& Grassland Research and Innovation Centre, Teagasc, Grange, Dunsany, Co. Meath, Ireland \\ ${ }^{2}$ School of Agriculture and Food Science, University College Dublin, Belfield, Dublin 4, Ireland \\ *e-mail: padraig.okiely@teagasc.ie
}

\begin{abstract}
The chemical composition, in vitro rumen fermentation variables and methane $\left(\mathrm{CH}_{4}\right)$ output of a range of common forb species sampled in spring and summer, and grass silage (14 treatments in total; triplicate replication), were determined in this study. Dried, milled herbage samples were incubated in an in vitro rumen batch culture with rumen microbial inoculum (rumen fluid) and buffered mineral solution (artificial saliva) at $39^{\circ} \mathrm{C}$ for 24 hours. All herbage chemical composition and in vitro rumen fermentation variables were affected by treatment, and more specifically by season, species, and season by species $(p<0.05)$, except the acetic acid to propionic acid ratio for which there was no season by species interaction $(p>0.05)$. Rumex obtusifolius (spring, summer), Urtica dioica (summer) and Senecio jacobaea (summer) had lower $(p<0.05) \mathrm{CH}_{4}$ outputs per unit of feed dry matter incubated $\left(\mathrm{CH}_{4} \mathrm{i}\right)$ compared with grass silage, and Stellaria media, $U$. dioica and $S$. jacobaea had lower $(p<0.05) \mathrm{CH}_{4}$ i in summer than in spring, reflecting their lower extent of in vitro rumen fermentation. Although Ranunculus repens (spring) and Cirsium arvense (spring) had lower $(p<0.001) \mathrm{CH}_{4}$ output than grass silage when expressed per unit of total volatile fatty acids and total gas produced, respectively, these outcomes were not congruent with the more methanogenic volatile fatty acid profile for the grass silage versus all forb treatments. Thus, further study is required to determine whether these forb species would reduce $\mathrm{CH}_{4}$ output relative to animal product if assessed in vivo.
\end{abstract}

Key words: greenhouse gas, grassland, weeds, fermentation

\section{Introduction}

Grassland is the dominant (approximately 0.9) crop on agricultural land in Ireland (O'Riordan and O'Kiely 1996), and any enteric methane $\left(\mathrm{CH}_{4}\right)$ mitigation strategies for ruminants must be effective within the predominantly grass-based production systems that prevail.

Previous studies have found that altering grazing management strategy by making specific changes to herbage mass and sward allowance, and choosing among specific perennial ryegrass varieties and perennial grass species, had little impact on in vitro rumen $\mathrm{CH}_{4}$ output (Purcell et al. 2011a, 2012 ). However, some forb species occurring naturally in grassland can have a high apparent nutritive value for grazing livestock (Fairbairn and Thomas 1959), and this could impact on enteric methanogenesis. However, the latter has not been confirmed.

The objective of this study was therefore to quantify the chemical composition, and in vitro rumen fermentation variables and $\mathrm{CH}_{4}$ output using a batch culture gas production technique, of a range of common forb species sampled in spring and summer, and of grass silage (GS). 


\section{AGRICULTURAL AND FOOD SCIENCE}

P. Purcell et al. (2012) 21: 83-90

\section{Materials and methods}

\section{Treatments}

All herbage samples were collected at Teagasc Grange, Dunsany, Co. Meath, Ireland (53 $30^{\prime} \mathrm{N}, 6^{\circ} 40^{\prime} \mathrm{W}$, $83 \mathrm{~m}$ above sea level), identified with reference to Webb (1977), and named according to the International Plant Names Index (2011). Except for the GS, which was made from a Lolium perenne (L.) dominant permanent grassland sward, samples were collected on both 30 April (2009; spring) and 29 August (2009; summer), or on 30 April only (Ranunculus repens only), from three separate field plots within permanent grass pastures. Samples were cut to a stubble height of $20 \mathrm{~mm}$. The 14 treatments included in this experiment were Stellaria media (L.) Vill. (spring, summer), Taraxacum officinale F.H. Wigg (spring, summer), Rumex obtusifolius (L.) (spring, summer), Urtica dioica (L.) (spring, summer), Cirsium arvense (L.) Scop. (spring, summer), Senecio jacobaea (L.) (spring, summer), Ranunculus repens (L.) (spring), and GS.

\section{Herbage chemical composition analyses}

Each herbage sample was initially stored at $-18^{\circ} \mathrm{C}$ before being thawed at $4{ }^{\circ} \mathrm{C}$ for 24 hours, bowl-chopped, and individually mixed. Subsamples of each herbage were thermally dried in a ventilated oven with forced air-circulation at $40^{\circ} \mathrm{C}$ for 48 hours prior to milling through a sieve with $1 \mathrm{~mm}$ apertures. Determination of in vitro dry matter (DM) digestibility (DMD) was carried out using the Tilley and Terry (1963) technique, and the final residue was isolated by filtration rather than centrifugation. The NDF (neutral detergent fibre assayed with a heat stable amylase and sodium sulphite, and expressed exclusive of residual ash), ADFsep (acid detergent fibre analysed on a sample separate from that analysed during the NDF assay and expressed exclusive of residual ash) and ADFseq (sequential analysis of acid detergent fibre on the residue from the NDF assay and expressed exclusive of residual ash; carried out for $R$. obtusifolius [spring, summer] only) concentrations were determined using the filter bag techniques (ANKOM $2006 \mathrm{a}$ and $\mathrm{b}$ ), and ash content was determined by complete combustion in a muffle furnace at $550{ }^{\circ} \mathrm{C}$ for 5 hours. The crude protein $(\mathrm{CP} ; \mathrm{N} \times 6.25)$ concentration was determined using a Leco FP $528 \mathrm{~N}$ analyser based on method 990-03 of the Association of Official Analytical Chemistry (AOAC, 1990), and the concentration of water soluble carbohydrate (WSC) was determined using the anthrone method (Thomas 1977).

\section{In vitro rumen incubation}

The in vitro rumen gas production technique of Purcell et al. (2011a) was employed in this study. Replication $(\times 3)$ for the in vitro rumen incubation was provided by the three independent field replicates. Approximately $0.5 \mathrm{~g}$ of each dried, milled feed sample was weighed into $160 \mathrm{ml}$ in vitro rumen fermentation bottles. Buffered mineral solution (artificial saliva) was prepared according to McDougall (1948). To obtain a source of rumen microbial inoculum, solid and liquid phase samples of rumen fluid (RF) were collected from different parts of the rumens of four rumen fistulated steers one hour prior to feeding. Each steer was individually offered a restricted allowance (0.9 of ad libitum intake) of a 60:40 (DM basis) grass silage plus concentrate diet, with fresh feed offered at 10:30 h daily. The RF was pooled across steers, after which the RF and buffered mineral solution were maintained at $39{ }^{\circ} \mathrm{C}$ and under a constant stream of carbon dioxide $\left(\mathrm{CO}_{2}\right)$ at all times. The RF was added to the buffered mineral solution at a ratio of 1:4 (RF:buffered mineral solution) after which $50 \mathrm{ml}$ of this buffered RF was dispensed into each fermentation bottle.

All inoculated fermentation bottles were flushed with $\mathrm{CO}_{2}$ before being sealed and incubated at $39^{\circ} \mathrm{C}$ for 24 hours. The gas headspace pressure inside each of the fermentation bottles was recorded at the end of the 24 hour incubation period using a detachable pressure transducer. The total gas produced (TGP) in 


\section{AGRICULTURAL AND FOOD SCIENCE}

P. Purcell et al. (2012) 21: 83-90

each bottle was estimated using the equation:

$T G P(\mathrm{ml})=\left(\frac{\text { bottle headspace volume }[\mathrm{ml}]}{\text { atmospheri c pressure }[\mathrm{hPa}]}\right) \times$ bottle headspace pressure $(\mathrm{hPa})$

A $0.8 \mathrm{ml}$ sample of gas was then transferred to a pre-evacuated $2 \mathrm{ml} \mathrm{screw}$-top glass vial for determination of $\mathrm{CH}_{4}$ concentration. A $0.8 \mathrm{ml}$ sample of liquid medium was obtained from each bottle, placed in $2 \mathrm{ml}$ Eppendorf tubes with $20 \mu \mathrm{l}$ of a $9 \mathrm{M} \mathrm{H}_{2} \mathrm{SO}_{4}$ solution, and stored at $-18{ }^{\circ} \mathrm{C}$ prior to volatile fatty acid (VFA) analysis. The $\mathrm{CH}_{4}$ and VFA concentrations were measured by gas chromatography using a Shimadzu GC17A with a flame ionisation detector using iso-caproic acid $(0.04 \mathrm{M})$ as an internal standard for the VFA as described by Ranfft (1973). Temperatures were $150^{\circ} \mathrm{C}$ in the column, $150{ }^{\circ} \mathrm{C}$ in the injector and $180{ }^{\circ} \mathrm{C}$ in the detector. The TGP for each sample was corrected by inclusion of blank fermentation bottles containing buffered RF only, and the mmol of total VFA per gram of feed DM incubated (tVFAi) were corrected using the total VFA concentrations of the pre-incubation buffered RF.

\section{Statistical analysis}

The experimental unit in this study was the independent field replicate of each species within each season. Data for the 14 independent treatments were analysed, and a contrast analysis between GS and the mean of all forbs was carried out, using the Proc MIXED procedure of the Statistical Analysis System (SAS, 2003). Differences between treatments were tested using a multiple comparison procedure (Tukey). Data for $S$. media, T. officinale, R. obtusifolius, $U$. dioica, $C$. arvense and $S$. jacobaea were also analysed using a model that accounted for season, species, and their interaction with the Proc MIXED procedure of the Statistical Analysis System (SAS, 2003). Where season by species interactions occurred, differences between seasons for individual species were tested using a multiple comparison procedure (Tukey).

\section{Results and discussion}

The forb species evaluated in this study are commonly found in permanent grassland in Ireland and other temperate regions, and were deemed to be of potentially high apparent nutritive value by Fairbairn and Thomas (1959). The GS was included as a reference feed for comparative purposes.

\section{Herbage chemical composition}

When analysed as 14 independent treatments, all herbage chemical composition variables were affected $(p<0.001)$ by treatment (Table 1$)$. The GS had a higher $(p<0.05)$ DMD than $R$. obtusifolius (summer) and $S$. jacobaea (summer) but did not differ $(p>0.05)$ from all other treatments. The GS had a higher $(p<0.05)$ NDF concentration than all other treatments, and ADFsep concentration was higher $(p<0.05)$ for GS than for all spring forb treatments except $R$. obtusifolius and $C$. arvense, but did not differ $(p>0.05)$ from any summer forb treatment except $T$. officinale, which was lower than GS $(p<0.05)$.

The ADFsep concentrations of $R$. obtusifolius in spring (265 g kg-1 DM) and summer (361 $\left.\mathrm{g} \mathrm{kg}^{-1} \mathrm{DM}\right)$ were higher than the corresponding NDF (169 and $291 \mathrm{~g} \mathrm{~kg}^{-1} \mathrm{DM}$ ) and ADFseq (118 and $199 \mathrm{~g} \mathrm{~kg}^{-1} \mathrm{DM}$ ) values. The apparent anomaly of the higher ADFsep concentrations can be explained by the high condensed tannin (CT) concentration of $R$. obtusifolius (Waghorn and Jones 1989) forming insoluble complexes with plant protein during oven drying (Pagán et al. 2009) and thus remaining in the ADFsep residue. In contrast, the sodium 


\section{AGRICULTURAL AND FOOD SCIENCE}

P. Purcell et al. (2012) 21: 83-90

sulphite used in the NDF assay likely removed much of the CT-protein complexes, thereby preventing a similar anomaly with NDF or ADFseq. Thus, this study confirms the conclusion of Terrill et al. (2010) that sequential NDF-ADF analysis provides more realistic ANKOM fibre estimates of ADF for oven-dried plant material containing condensed tannins compared with separate ADF analysis.

The GS had a lower $(p<0.05)$ CP concentration than R. obtusifolius (spring) and U. dioica (spring) but did not differ $(p>0.05)$ from the other treatments. The WSC concentration for GS was either lower $(p<0.05)$ than or did not differ $(p>0.05)$ from all forb treatments. Ash concentration was lower $(p<0.05)$ for GS than for nine of the 13 other treatments (Table 1 ).

Table 1. In vitro dry matter (DM) digestibility (DMD; $\mathrm{g} \mathrm{kg}^{-1}$ ) and chemical composition of the forb species in spring and summer and of grass silage (GS)

\begin{tabular}{|c|c|c|c|c|c|c|}
\hline & DMD & NDF & ADFsep & $\mathrm{CP}$ & WSC & Ash $\left(\mathrm{g} \mathrm{kg}^{-1} \mathrm{DM}\right)$ \\
\hline \multicolumn{7}{|l|}{ Treatment } \\
\hline \multicolumn{7}{|l|}{ Spring } \\
\hline Stellaria media (L.) Vill. & 817 & 329 & 210 & 169 & 88 & 121 \\
\hline $\begin{array}{l}\text { Taraxacum officinale F.H. } \\
\text { Wigg }\end{array}$ & 810 & 225 & 189 & 205 & 152 & 91 \\
\hline Rumex obtusifolius (L.) & 646 & 169 & 265 & 296 & 85 & 92 \\
\hline Urtica dioica (L.) & 810 & 259 & 165 & 278 & 69 & 162 \\
\hline Cirsium arvense (L.) Scop. & 763 & 348 & 254 & 221 & 155 & 146 \\
\hline Senecio jacobaea (L.) & 852 & 194 & 155 & 154 & 52 & 125 \\
\hline Ranunculus repens (L.) & 716 & 276 & 222 & 187 & 126 & 109 \\
\hline \multicolumn{7}{|l|}{ Summer } \\
\hline Stellaria media (L.) Vill. & 707 & 419 & 266 & 119 & 97 & 166 \\
\hline $\begin{array}{l}\text { Taraxacum officinale F.H. } \\
\text { Wigg }\end{array}$ & 725 & 308 & 197 & 207 & 63 & 173 \\
\hline Rumex obtusifolius (L.) & 514 & 291 & 361 & 228 & 61 & 119 \\
\hline Urtica dioica (L.) & 686 & 390 & 293 & 182 & 41 & 182 \\
\hline Cirsium arvense (L.) Scop. & 708 & 357 & 283 & 91 & 75 & 175 \\
\hline Senecio jacobaea (L.) & 571 & 444 & 348 & 123 & 144 & 93 \\
\hline GS & 739 & 521 & 332 & 145 & 17 & 82 \\
\hline SEM & 27.8 & 12.5 & 21.2 & 16.6 & 13.5 & 6.2 \\
\hline Sig & $* * *$ & $* * *$ & $* * *$ & $* * *$ & $* * *$ & $* * *$ \\
\hline \multicolumn{7}{|l|}{ GS versus forbs } \\
\hline SEM & 17.1 & 7.93 & 13.2 & 10.4 & 8.5 & 3.9 \\
\hline Sig & NS & $* * *$ & $* * *$ & $*$ & $* * *$ & $* * *$ \\
\hline \multicolumn{7}{|l|}{ Species } \\
\hline SEM & 11.4 & 9.80 & 16.2 & 12.8 & 10.4 & 4.8 \\
\hline Sig & $* * *$ & $* * *$ & $* *$ & $* * *$ & $* *$ & $* * *$ \\
\hline \multicolumn{7}{|l|}{ Season } \\
\hline SEM & 6.6 & 5.67 & 9.4 & 7.4 & 6.0 & 2.8 \\
\hline Sig & $* * *$ & $* * *$ & $* * *$ & $* * *$ & $*$ & $* * *$ \\
\hline \multicolumn{7}{|l|}{ Species $\times$ season } \\
\hline SEM & 16.2 & 13.85 & 22.9 & 18.1 & 14.7 & 6.7 \\
\hline Sig & $* * *$ & $* * *$ & $* *$ & $*$ & $* * *$ & $* * *$ \\
\hline
\end{tabular}

Abbreviations: Spring, 30 April; Summer, 29 August; NDF, neutral detergent fibre assayed with a heat stable amylase and sodium sulphite, and expressed exclusive of residual ash ( $\left.\mathrm{g} \mathrm{kg}^{-1} \mathrm{DM}\right)$; ADFsep, acid detergent fibre analysed on a sample separate from that analysed during the NDF assay and expressed exclusive of residual ash $\left(\mathrm{g} \mathrm{kg}^{-1} \mathrm{DM}\right)$; CP, crude protein ( $\left.\mathrm{g} \mathrm{kg}^{-1} \mathrm{DM}\right)$; WSC, water soluble carbohydrate $\left(\mathrm{g} \mathrm{kg}^{-1} \mathrm{DM}\right)$; Sig, significance; ***, $p<0.001 ; * *, p<0.01 ; *, p<0.05 ; \mathrm{NS}$, 


\section{AGRICULTURAL AND FOOD SCIENCE}

P. Purcell et al. (2012) 21: 83-90

not significant.

Overall, the GS did not differ ( $p>0.05)$ in DMD from the mean of all forbs, but had higher $(p<0.001)$ NDF and ADFsep concentrations, and lower $(p<0.05)$ CP, WSC and ash concentrations (Table 1).

When analysed as a two-factor model, all herbage chemical composition variables were affected by species, season, and had species by season interactions ( $p<0.05$; Table 1$)$. The Tukey adjusted comparisons indicate that the effect of season on individual species was either in agreement with or did not contradict the overall effect of season for all herbage chemical composition variables, except for WSC concentration where S. jacobaea was lower $(p<0.05)$ in spring than in summer. The DMD for S. media, R. obtusifolius, $U$. dioica and $S$. jacobaea were higher $(p<0.01)$ in spring than in summer, and NDF concentration was lower $(p<0.01)$ in spring for all species except $T$. officinale and $C$. arvense. Both $U$. dioica and $S$. jacobaea had lower $(p<0.05)$ ADFsep concentrations in spring, and $U$. dioica and $C$. arvense had higher $(p<0.05) C P$ concentrations in spring compared to in summer. The WSC concentrations for $T$. officinale and $C$. arvense were higher $(p<0.05)$, while S. jacobaea was lower $(p<0.05)$, in spring, and S. media and T. officinale had lower $(p<0.01)$ ash concentration in spring versus summer.

\section{In vitro rumen fermentation variables}

When analysed as 14 independent treatments, all in vitro rumen fermentation variables were affected by treatment $\left(p<0.001\right.$; Table 2). The lower $(p<0.05) \mathrm{ml}$ of $\mathrm{CH}_{4}$ output per gram of feed DM incubated $\left(\mathrm{CH}_{4} \mathrm{i}\right)$ for $\mathrm{R}$. obtusifolius compared to GS in both spring and summer reflected its lower extent of in vitro rumen fermentation as evidenced by its lower $(p<0.05) \mathrm{ml}$ of TGP per gram of feed DM incubated (TGPi) in spring, and its lower $(p<0.05)$ TGPi and tVFAi in summer. Furthermore, the likely presence of CT in $R$. obtusifolius (Waghorn and Jones 1989), which can reduce methanogenesis (Min et al. 2005, Tavendale et al. 2005, Puchala et al. 2005), may have also contributed to its lower $\mathrm{CH}_{4}$ i. Similar to R. obtusifolius, the lower $(p<0.05) \mathrm{CH}_{4}$ i for $U$. dioica and $S$. jacobaea compared to GS in summer reflects their lower extent of fermentation as evidenced by their lower $(p<0.05)$ TGPi values, and also the lower $(p<0.05)$ tVFAi for $U$. dioica (summer), compared with GS. The GS did not differ ( $p>0.05$ ) in $\mathrm{mmol}$ of $\mathrm{CH}_{4}$ output per mmol of tVFA output $\left(\mathrm{CH}_{4} / \mathrm{tVFA}\right)$ from other treatments except for $R$. repens (spring) and $S$. media (summer), which were lower $(p<0.001)$ and higher $(p<0.05)$, respectively, than the GS. For mmol of $\mathrm{CH}_{4}$ output per mmol of TGP $\left(\mathrm{CH}_{4} / \mathrm{TGP}\right)$, the GS was lower $(p<0.001)$ and higher $(p<0.05)$, respectively, than $U$. dioica (spring) and $C$. arvense (spring), but did not differ ( $p>0.05)$ from any other treatments.

The less methanogenic direction of the fermentation of the GS compared to the forb treatments, as evidenced by its lower $(p<0.001)$ acetic acid to propionic acid ratio $(A: P)$ and non-glucogenic to glucogenic VFA ratio (NGGR; (acetic acid + [butyric acid $\times 2$ ]) / propionic acid), most likely reflects the higher NDF concentration of the GS, and would be expected to lead to a reduction in $\mathrm{CH}_{4}$ output relative to total VFA and TGP due to a reduction in $\mathrm{H}_{2}$ production per unit of feed digested (Janssen 2010). Considering this, the finding that the GS did not differ $(p>0.05)$ in $\mathrm{CH}_{4} / \mathrm{tVFA}$ or $\mathrm{CH}_{4} / \mathrm{TGP}$ from all but two of the 13 other treatments for both variables was surprising.

Overall, there were no differences $(p>0.05)$ in $\mathrm{CH}_{4}$ output between the GS and the mean of all forbs, whether expressed relative to feed DM incubated $\left(\mathrm{CH}_{4} \mathrm{i}\right)$, TGP $\left(\mathrm{CH}_{4} / \mathrm{TGP}\right)$, or tVFA $\left(\mathrm{CH}_{4} / \mathrm{tVFA}\right)$. There was also no difference $(p>0.05)$ in tVFAi between GS and the mean of all forbs. However, the GS had a higher $(p<0.05)$ TGPi, and a lower $(p<0.001)$ A:P and NGGR, than the mean of all forbs. 


\section{AGRICULTURAL AND FOOD SCIENCE}

P. Purcell et al. (2012) 21: 83-90

Table 2. In vitro rumen fermentation variables of forb species in spring and summer and grass silage (GS) after 24 hours of batch culture fermentation.

\begin{tabular}{|c|c|c|c|c|c|c|c|}
\hline & $\mathrm{CH}_{4} \mathrm{i}$ & $\begin{array}{l}\mathrm{CH}_{4} / \\
\text { tVFA }\end{array}$ & $\begin{array}{l}\mathrm{CH}_{4} / \\
\mathrm{TGP}\end{array}$ & TGPi & tVFAi & $\mathrm{A}: \mathrm{P}$ & NGGR \\
\hline \multicolumn{8}{|l|}{ Treatment } \\
\hline \multicolumn{8}{|l|}{ Spring } \\
\hline Stellaria media (L.) Vill. & 32.9 & 0.270 & 0.162 & 184 & 4.80 & $2.99^{c}$ & 3.17 \\
\hline $\begin{array}{l}\text { Taraxacum officinale F.H. } \\
\text { Wigg }\end{array}$ & 30.9 & 0.230 & 0.142 & 196 & 5.29 & 2.98 & 3.16 \\
\hline Rumex obtusifolius (L.) & 20.5 & 0.216 & 0.137 & 131 & 3.71 & 3.36 & 3.55 \\
\hline Urtica dioica (L.) & 30.3 & 0.260 & 0.174 & 156 & 4.59 & 3.53 & 3.76 \\
\hline Cirsium arvense (L.) Scop. & 22.1 & 0.191 & 0.127 & 156 & 5.14 & 3.07 & 3.26 \\
\hline Senecio jacobaea (L.) & 29.6 & 0.226 & 0.145 & 184 & 4.54 & 3.11 & 3.33 \\
\hline Ranunculus repens (L.) & 29.7 & 0.168 & 0.145 & 187 & 5.16 & 3.16 & 3.39 \\
\hline \multicolumn{8}{|l|}{ Summer } \\
\hline Stellaria media (L.) Vill. & 28.2 & 0.285 & 0.163 & 155 & 3.90 & 3.35 & 3.56 \\
\hline Taraxacum officinale F.H. Wigg & 30.5 & 0.252 & 0.160 & 171 & 4.77 & 3.52 & 3.74 \\
\hline Rumex obtusifolius (L.) & 20.3 & 0.263 & 0.161 & 108 & 3.04 & 3.60 & 3.82 \\
\hline Urtica dioica (L.) & 22.1 & 0.241 & 0.155 & 125 & 3.62 & 3.52 & 3.76 \\
\hline Cirsium arvense (L.) Scop. & 25.3 & 0.238 & 0.141 & 162 & 3.34 & 3.13 & 3.34 \\
\hline Senecio jacobaea (L.) & 19.4 & 0.231 & 0.139 & 122 & 4.20 & 3.53 & 3.74 \\
\hline GS & 27.6 & 0.236 & 0.147 & 169 & 4.60 & 2.17 & 2.33 \\
\hline SEM & 0.8 & 0.0090 & 0.0033 & 4.9 & 0.18 & 0.09 & 0.084 \\
\hline Sig & $* * *$ & $* * *$ & $* * *$ & $* * *$ & $* * *$ & $* * *$ & $* * *$ \\
\hline \multicolumn{8}{|l|}{ GS versus forbs } \\
\hline SEM & 0.51 & 0.0058 & 0.0021 & 3.11 & 0.115 & 0.058 & 0.054 \\
\hline Sig & NS & NS & NS & $*$ & NS & $* * *$ & $* * *$ \\
\hline \multicolumn{8}{|l|}{ Species } \\
\hline SEM & 0.55 & 0.0067 & 0.0022 & 3.7 & 0.137 & 0.068 & 0.062 \\
\hline Sig & $* * *$ & $* * *$ & $* * *$ & $* * *$ & $* * *$ & $* * *$ & $* * *$ \\
\hline \multicolumn{8}{|l|}{ Season } \\
\hline SEM & 0.32 & 0.0039 & 0.0013 & 1.94 & 0.073 & 0.039 & 0.036 \\
\hline Sig & $* * *$ & $* *$ & $* *$ & $* * *$ & $* * *$ & $* * *$ & $* * *$ \\
\hline \multicolumn{8}{|l|}{ Species $\times$ season } \\
\hline SEM & 0.77 & 0.0095 & 0.0031 & 4.76 & 0.179 & 0.096 & 0.088 \\
\hline Sig & $* * *$ & $*$ & $* * *$ & $* * *$ & $* *$ & NS & $*$ \\
\hline
\end{tabular}

Abbreviations: Spring, 30 April; Summer, 29 August; $\mathrm{CH}_{4} \mathrm{i}, \mathrm{ml}$ of methane output per gram of feed dry matter (DM) incubated; $\mathrm{CH}_{4} / \mathrm{tVFA}$, mmol of $\mathrm{CH}_{4}$ output per mmol of tVFA output; $\mathrm{CH}_{4} / \mathrm{TGP}$, mmol of $\mathrm{CH}_{4}$ output per mmol of TGP; TGPi, $\mathrm{ml}$ of total gas produced (TGP) per gram of feed DM incubated; tVFAi, mmol of total volatile fatty acid (tVFA) per gram of feed DM incubated; A:P, the acetic acid to propionic acid ratio; NGGR, the non-glucogenic to glucogenic volatile fatty acid ratio $(($ acetic acid $+($ butyric acid $\times 2)) /$ propionic acid $)$; Sig, significance; $* * *, p<0.001 ; * *, p<0.01 ; *, p<0.05$; NS, not significant.

When analysed using a two-factor model, all in vitro rumen fermentation variables were affected by season and species, and there were season by species interactions for all in vitro rumen fermentation variables $(p<0.05)$, except for the A:P ratio $(p=0.059)$. When contrasted using Tukey adjusted comparisons, the effect of season on individual species was either in agreement with or did not contradict the overall effect of season for all in vitro rumen fermentation variables, except for $\mathrm{CH}_{4} / \mathrm{TGP}$ where $U$. dioica was higher 


\section{AGRICULTURAL AND FOOD SCIENCE}

P. Purcell et al. (2012) 21: 83-90

$(p<0.05)$ in spring versus summer. S. media, U. dioica and S. jacobaea had higher $(p<0.05) \mathrm{CH}_{4} \mathrm{i}$ in spring than in summer, which reflects their generally more extensive in vitro rumen fermentations, namely their higher $(p<0.05)$ TGPi, and the higher tVFAi for U. dioica and S. jacobaea $(p<0.05)$, in spring compared to summer. This apparent relationship between the extent of in vitro rumen fermentation and $\mathrm{CH}_{4}$ output expressed relative to feed DM incubated is in accord with Purcell et al. (2011b) and Navarro-Villa et al. (2011), and was most likely due to the higher DMD of these species in spring than in summer.

Despite the overall lower $(p<0.01) \mathrm{CH}_{4} /$ tVFA and $\mathrm{CH}_{4} /$ TGP in spring than in summer, there were no differences $(p>0.05)$ in $\mathrm{CH}_{4} /$ tVFA between spring and summer for any individual species, and no differences $(p>0.05)$ in $\mathrm{CH}_{4} /$ TGP between spring and summer for $\mathrm{S}$. media, $C$. arvense or $S$. jacobaea. These outcomes are in partial agreement with the relative proportions of the main VFA produced, and thus with the direction of the in vitro rumen fermentation, namely the lack of differences $(p>0.05)$ in NGGR between these species.

In conclusion, this study established that some forb species had lower in vitro rumen $\mathrm{CH}_{4}$ output compared to GS, and some were lower in summer compared to in spring, when expressed per unit of feed DM incubated. However, these lower $\mathrm{CH}_{4}$ i outputs appear to have been achieved mainly through a reduction in the extent of in vitro rumen fermentation, as supported by the correspondingly lower TGPi and/or tVFAi values. Although $R$. repens (spring) and $C$. arvense (spring) had lower $\mathrm{CH}_{4}$ output than $\mathrm{GS}$ when expressed relative to TVFA and TGP, respectively, these outcomes were not congruent with the more methanogenic in vitro rumen VFA profile of the GS versus the forbs, namely its higher A:P and NGGR. Thus, further evaluation is required to determine whether these forb species would reduce $\mathrm{CH}_{4}$ output relative to animal product if assessed in vivo.

\section{Acknowledgements}

The authors acknowledge B. Weldon, G. Costello and the staff of Grange Laboratories for their input into this study. Funding for this study was provided by the Department of Agriculture, Food and the Marine Research Stimulus Fund (07 517).

\section{References}

ANKOM 2006a. Acid detergent fiber in feeds filter bag technique. ANKOM Technology, Macedon, NY. ANKOM 2006b. Neutral detergent fiber in feeds filter bag technique. ANKOM Technology, Macedon, NY.

Association of Official Analytical Chemistry 1990. Official methods of analysis. Association of Official Analytical Chemistry 15: 3-4.

Fairbairn, C.B. \& Thomas, B. 1959. The potential nutritive value of some weeds common to north-eastern England. Journal of the British Grassland Society 14: 36-46.

International Plant Names Index. Updated 3 November 2011. Cited 25 January 2012. Available on the internet: http:// www.ipni.org/index.html

Janssen, P.H. 2010. Influence of hydrogen on rumen methane formation and fermentation balances through microbial growth kinetics and fermentation thermodynamics. Animal Feed Science and Technology 160: 1-22.

McDougall, E.I. 1948. Studies on ruminant saliva i. The composition and output of sheep's saliva. Biochemical Journal 43: 99-109.

Min, B.R., Pinchak, W.E., Fulford, J.D. \& Puchala, R. 2005. Wheat pasture bloat dynamics, in vitro ruminal gas production, and potential bloat mitigation with condensed tannins. Journal of Animal Science 83: 1322-1331.

Navarro-Villa, A., O’Brien, M., López, S., Boland, T. \& O’Kiely, P. 2011. In vitro rumen methane output of red clover 


\section{AGRICULTURAL AND FOOD SCIENCE}

P. Purcell et al. (2012) 21: 83-90

and perennial ryegrass assayed using the gas production technique (GPT). Animal Feed Science and Technology 168: 152-164.

O’ Riordan, E. \& O'Kiely, P. 1996. Potential for beef production systems based on grass. Irish Grassland and Animal Production Association Journal 30: 185-217.

Pagán, S., Wolfe, R.M., Terrill, T.H. \& Muir, J.P. 2009. Effect of drying method and assay methodology on detergent fibre analysis in plants containing condensed tannins. Animal Feed Science and Technology 154: 119-124.

Puchala, R., Min, B.R., Goetsch, A.L. \& Sahlu, T. 2005. The effect of a condensed tannin-containing forage on methane emission by goats. Journal of Animal Science 83: 182-186.

Purcell, P.J., O’Brien, M., Boland, T.M., O’Donovan, M. \& O'Kiely, P. 2011a. Impacts of herbage mass and sward allowance of perennial ryegrass sampled throughout the growing season on in vitro rumen methane production. Animal Feed Science and Technology 166-167: 405-411.

Purcell, P.J., O’Brien, M., Boland, T.M. \& O'Kiely, P. 2011b. In vitro rumen methane output of perennial ryegrass samples prepared by freeze drying or thermal drying $\left(40^{\circ} \mathrm{C}\right)$. Animal Feed Science and Technology 166-167: $175-182$.

Purcell, P.J., O’Brien, M., Navarro-Villa, A., Boland, T.M., McEvoy, M., Grogan, D. \& O'Kiely, P. 2012. In vitro rumen methane output of perennial ryegrass varieties and perennial grass species harvested throughout the growing season. Grass and Forage Science Article published online at DOI: 10.1111/j.1365-2494.2011.00845.x

Ranfft, K. (1973) Gas-chromatography determination of short-chain volatile fatty acids in the ruminal fluid. Arch Tierernahr 23: 343-352.

SAS, 2003. Statistical Analysis System. SAS Inc., Cary, NC.

Tavendale, M.H., Meagher, L.P., Pacheco, D., Walker, N., Attwood, G.T. \& Sivakumaran, S. 2005. Methane production from in vitro rumen incubations with Lotus pedunculatus and Medicago sativa, and effects of extractable condensed tannin fractions on methanogenesis. Animal Feed Science and Technology 123-124: $403-419$.

Terrill, T.H., Wolfe, R.M. \& Muir, J.P. 2010. Factors affecting ANKOM $^{\mathrm{TM}}$ fiber analysis of forage and browse varying in condensed tannin concentration. Journal of the Science of Food and Agriculture 90: 2723-2726.

Thomas, T.A. 1977. An automated procedure for the determination of soluble carbohydrates in herbage. Journal of the Science of Food and Agriculture 28: 639-642.

Tilley, J.M.A. \& Terry, R.A. 1963. A two-stage technique for the in vitro digestion of forage crops. Journal of the British Grassland Society 18: 104-111.

Waghorn, G.C. \& Jones, W.T. 1989. Bloat in cattle. Potential of dock (Rumex obtusifolius) as an antibloat agent for cattle. New Zealand Journal of Agricultural Research 32: 227-235.

Webb, D.A. 1977. An Irish flora. $6^{\text {th }}$ revised edition. Dundalgan Press, Dundalk, Co. Louth. 277 p. 